\title{
Analysis of Chemical and Biological Soil Properties in Organically and Conventionally Fertilized Apple Orchards
}

\author{
Takamitsu Kai, Masaki Mukai, Kiwako S. Araki, Dinesh Adhikari, Motoki Kubo \\ Department of Biotechnology, Faculty of Life Sciences, Ritsumeikan University, Kusatsu, Japan \\ Email:kubo@sk.ritsumei.ac.jp
}

Received 26 February 2016; accepted 9 May 2016; published 12 May 2016

Copyright (C) 2016 by authors and Scientific Research Publishing Inc.

This work is licensed under the Creative Commons Attribution International License (CC BY). http://creativecommons.org/licenses/by/4.0/

\section{(c) (i) Open Access}

\begin{abstract}
We compared chemical and biological properties of soils in organically and conventionally fertilized apple orchards in Nagano Prefecture (one of the major apple producing regions in Japan). Five apple orchards with different fertilizer management systems were used for this study. The total carbon and total nitrogen contents were higher in the organically fertilized orchard, while the total phosphorus and total potassium were at similar levels in both organically and conventionally fertilized orchards. The bacterial biomass did not differ between the two orchards, but the $\mathrm{N}$ circulation activity was clearly higher in the organically fertilized orchard from April to December. Total carbon from 50,000 to $60,000 \mathrm{mg} / \mathrm{kg}$, total nitrogen at about 3000 to $4000 \mathrm{mg} / \mathrm{kg}$, and a $\mathrm{C} / \mathrm{N}$ ratio of 15 - 20 were suggested to be suitable conditions for a high level of apple production under an organic fertilizer management system.
\end{abstract}

\section{Keywords}

Component, Formatting, Style, Styling, Insert, Organic Fertilizer Management System, Apple, Bacterial Biomass, Nitrogen Circulation Activity

\section{Introduction}

Apples (Malus domestica Borkh.) are one of the old cultivated fruits in Japan and several other countries [1] [2]. Apple cultivation requires a deep and well-drained soil with a pH of 5.5 to 6.5 [3]. Soils rich in organic matter and high in available nitrogen, phosphorus, and potassium are most suitable for apple cultivation. In Japan, ap- 
ple is cultivated conventionally, relying on the use of large amounts of chemical fertilizers and pesticides. Only $1.4 \%$ of the apple and other temperate organic fruit orchards (about $1100 \mathrm{ha}$ ) are under organic production systems [4].

The average productivity of apples in Japan is $21.2 \mathrm{t} \cdot \mathrm{ha}^{-1}$, which is lower than that in other developed countries, such as $77.9 \mathrm{t} \cdot \mathrm{ha}^{-1}$ in Austria $47.4 \mathrm{t} \cdot \mathrm{ha}^{-1}$ in New Zealand, and $31.9 \mathrm{t} \cdot \mathrm{ha}^{-1}$ in the USA [5]. Poor soil fertility seems to be one of the most important reasons for low apple productivity in Japan [1].

Besides chemical fertilizers, two other fertilizer management systems are also practiced for cultivating apple: the integration of organic and chemical fertilizers and the use of organic fertilizers only [6]-[8]. Previous studies suggest that productivity under organic agricultural systems is $20 \%$ to $30 \%$ lower than that under conventional chemical fertilizer systems [7] [9]. Stable and high agricultural productivity from organic fertilizer based systems can be achieved by improving the number and activity of soil microorganisms through the control of the total carbon (TC), total nitrogen (TN), and $\mathrm{C} / \mathrm{N}$ ratio in soil [10]. Apple orchards are relatively rich in TC, TN, total phosphorus (TP), and total potassium (TK), compared with the annual croplands such as uplands and paddy fields (Kai et al., 2015). Therefore, the soil fertility improvement under organic fertilizer management systems should be considered for orchard soils specifically.

We have previously studied the effects of physical and biochemical properties of soil on apple productivity under the chemical fertilizer management system and have found that too much TC, TN, TP, and TK lead to yield reduction [11]. In the current study, we compare soil fertility between organically and chemically fertilize apple orchards to determine the suitable soil conditions needed to enhance microbial numbers and activity in an organic fertilizer management system.

\section{Materials and Methods}

\subsection{Study Sites}

In 2014, we selected five high yielding apple orchards in Nagano Prefecture, Japan (Orchards A, B, C, D, and E) differing in fertilizer management system (Figure 1). All of the orchards were 10 to 30 years old. The climate of Nagano Prefecture is humid temperate, where July is the warmest and January is the coolest month.

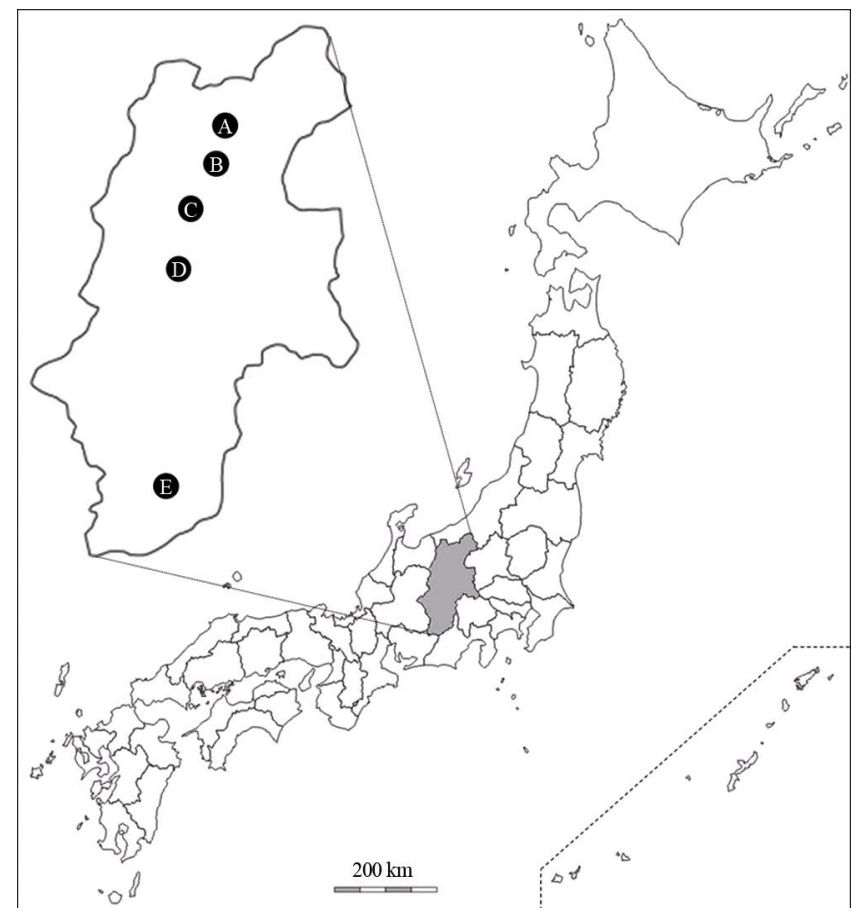

Figure 1. Map of Japan showing locations of the five apple orchards in this study. A, Iizuna Town; B, Nagano City; C, Sakaki Town; D, Ashahi Village; and E, Matsukawa Town. 
The main difference between the five selected orchards is fertilizer management. The orchards can be divided into three categories based on the fertilizer management system used over the past 10 years or more: 1 ) conventional (use of chemical fertilizers only) (Orchards A and D); 2) conventional + organic (Orchards B and E) and; 3) organic only (Orchard C). In Orchards A and D, chemical fertilizers are applied at the rate of $144 \mathrm{~kg} N, 72 \mathrm{~kg}$ $\mathrm{P}_{2} \mathrm{O}_{5}, 48 \mathrm{~kg} \mathrm{~K} \mathrm{~K}_{2}, 4.8 \mathrm{~kg} \mathrm{MnO}$, and $2.4 \mathrm{~kg} \mathrm{~B}$ per hectare, annually. Total fertilizer is split into two halves and applied in December (after harvesting) and in March (before flowering). In Orchard C, cattle manure is applied annually at the rate of $35 \mathrm{t} / \mathrm{ha}$. In Orchards B and E, rice straw is applied at the rate of $1.2 \mathrm{t} / \mathrm{ha}$ in combination with the chemical fertilizers at the same rate to those in orchards A and D. In all orchards, pesticides are applied according to the recommendations by the Nagano Prefecture Agricultural Policy and Planning Department, Japan [12].

\subsection{Chemical Properties of Soils}

Composite soils samples (top $15 \mathrm{~cm}$ except for the top 2 - $3 \mathrm{~cm}$ surface crust) were taken near the bases of five randomly selected trees. The following chemical properties of the composite soil samples were analyzed: TC, $\mathrm{TN}$, ammonium-nitrogen $\left(\mathrm{NH}_{4}^{+}-\mathrm{N}\right)$, nitrate-nitrogen $\left(\mathrm{NO}_{3}^{-}-\mathrm{N}\right)$, TP, water soluble phosphorus (SP), TK, and water soluble potassium (SK). The TC content was analyzed with a TOC analyzer (Model: SSM-5000A, Shimadzu, Kyoto, Japan). $\mathrm{NH}_{4}^{+}-\mathrm{N}$ and $\mathrm{NO}_{3}^{-}-\mathrm{N}$ were analyzed by extracting the soil sample with $1 \mathrm{M} \mathrm{KCl}$ followed by indophenol blue method and brucine method [13]. To analyze the SP and SK the soil-water suspension $(1: 20, \mathrm{w} / \mathrm{v})$ was shaken reciprocally at $100 \mathrm{rpm}$ for $1 \mathrm{~h}$ and the extracts were analyzed for by the-molybdenum blue method [14] and atomic absorption spectrophotometry, respectively. The TN, TP, and TK contents were analyzed by digesting soils in a Kjeldahl Therm digestion unit (Gerhardt, Königswinter, Germany) with $\mathrm{H}_{2} \mathrm{SO}_{4}$ and $\mathrm{H}_{2} \mathrm{O}_{2}$, followed by determinations of $\mathrm{NH}_{4}^{+}-\mathrm{N}$, SP and SK in the digest. The pH of the soil-water suspension (1:2.5, w/v) was analyzed using a pH meter (Model: LAQUA F-72, Horiba Scientific, Kyoto Japan).

\subsection{Biological Properties of Soils}

The following biological properties were analyzed: total bacterial biomass, ammonium oxidation activity, nitrite oxidation activity, $\mathrm{N}$ circulation activity, and $\mathrm{P}$ circulation activity. Total bacterial biomass was estimated by quantification of environmental DNA (eDNA) using the slow-stirring method following the procedures of Aoshima et al. [15]. The $\mathrm{N}$ circulation activity was analyzed using the values of ammonium oxidizing activity, nitrite oxidizing activity, and total bacterial number as described by [10] [16]. The P circulation activity was determined by analyzing the rate of release of soluble $\mathrm{P}$ from phytic acid (a dominant form of organic $\mathrm{P}$ in soil) during a 3-day incubation period [17] T. Kai et al.

\subsection{Nutrient Contents in Leaves and Fruits}

Leaves were sampled during July and fruit was sampled during December. A composite sample was prepared from five randomly chosen trees in each orchard. The TN, TP, and TK in leaves and fruits were analyzed by digesting leaf or fruit tissues in a KjeldahlTherm digestion unit following the same procedures as described above for soil samples.

\section{Results}

\subsection{General Features of Apple Orchards in Nagano Prefecture}

Fertilizer management system, average yield, and soil properties (TC, TN, TP, TK, and bacterial biomass) in the five apple orchards A-E are shown in Table 1. The average yields in the five orchards ranged from 30 to 50 t/ha. The TC, TN, and TK contents in the orchards ranged between 22,900 and 58,000 mg/kg, 1600 and $3970 \mathrm{mg} / \mathrm{kg}$, and 6130 and $9600 \mathrm{mg} / \mathrm{kg}$, respectively, while a wide range was observed in TP (2430 - 10,870 mg/kg). Most of the apple orchard soils were rich in TC, irrespective of the fertilizer management system, suggesting that the large amount of fallen leaves increased the TC levels in the apple orchard soils. The bacterial biomass in the soil also varied between the orchards (range: $5.7 \times 10^{8}$ to $11.4 \times 10^{8}$ cells/g). Bacterial biomass was enhanced under the organic fertilizer management system and in response to the amounts of TC in the soil. 
Table 1. Fertilizer management, yield, soil chemical properties, and bacterial biomass in five differently fertilized apple orchards (Orchards A-C).

\begin{tabular}{ccccccccc}
\hline Orchard & Location & $\begin{array}{c}\text { Fertilizer } \\
\text { management }^{\mathrm{a}}\end{array}$ & $\begin{array}{c}\text { Yield } \\
(\mathrm{t} / \mathrm{ha})\end{array}$ & $\begin{array}{c}\mathrm{TC} \\
(\mathrm{mg} / \mathrm{kg})\end{array}$ & $\begin{array}{c}\mathrm{TN} \\
(\mathrm{mg} / \mathrm{kg})\end{array}$ & $\begin{array}{c}\mathrm{TP} \\
(\mathrm{mg} / \mathrm{kg})\end{array}$ & $\begin{array}{c}\mathrm{TK} \\
(\mathrm{mg} / \mathrm{kg})\end{array}$ & $\begin{array}{c}\text { Bacterial biomass } \\
\left(\times 10^{8} \text { cells/g) }\right.\end{array}$ \\
\hline A & Iizuna Town & Conv. & 30 & 42,400 & 3230 & 2430 & 7270 & 8.9 \\
B & Nagano City & Org. + Conv. & 50 & 22,900 & 1600 & 4570 & 9600 & 5.7 \\
C & Sakaki Town & Org. & 45 & 53,700 & 3570 & 5730 & 6800 & 11.4 \\
D & Ashahi Village & Conv. & 50 & 48,800 & 2130 & 10,870 & 8770 & 6.4 \\
E & Matsukawa Town & Org. + Conv. & 45 & 58,000 & 3970 & 7830 & 6130 & 9.3 \\
Average & & & 44 & 45,160 & 2900 & 6290 & 7110 & 8.3 \\
\hline
\end{tabular}

${ }^{\mathrm{a}}$ Conv. $=$ conventional, Org. $=$ organic.

\subsection{Comparison of Chemical Properties of Soils between Organically and Conventionally Fertilized Apple Orchards}

The organically and conventionally fertilized orchards (Orchards C and D, respectively) were selected to consider the chemical properties of soils sampled from April to December (Table 2). The average apple productivity in these two orchards was almost the same (i.e., 45 to 50 t/ha). The TC and TN contents were higher in Orchard C than in Orchard D; however, the TP and TK contents were higher in Orchard D throughout the observation period. Seasonal variations in TP and TK were observed in both orchards, but no significant differences were found. Inorganic $\mathrm{N}\left(\mathrm{NH}_{4}^{+}-\mathrm{N}\right.$ and $\left.\mathrm{NO}_{3}^{-}-\mathrm{N}\right)$, SP, and $\mathrm{SK}$ contents were slightly higher in Orchard $\mathrm{C}$ in April, but no differences were observed in July and December. Higher TP and TK contents but lower SP and SK contents in Orchard D than Orchard $\mathrm{C}$ indicate that the rate of fixation of $\mathrm{P}$ and $\mathrm{K}$ is increased under the chemical fertilizer management system.

\subsection{Comparison of Biological Properties of Soils between Organically and Conventionally Fertilized Apple Orchards}

Biological properties of soils in organically and conventionally fertilized orchards (Orchards C and D) from April to December are shown in Table 3. Bacterial biomass in April and July were at the same level in the two orchards, but the bacterial biomass in Orchard C was about 3 times higher than that of Orchard D in December. The $\mathrm{N}$ circulation activities were $63 \%$ to $83 \%$ higher in Orchard $\mathrm{C}$ than Orchard D throughout the observation period from April to December (Figure 2). The P circulation activity in Orchard C was higher than that in Orchard D in April, but it became lower than Orchard D in July and December. The soil conditions in an organically fertilized field seem suitable for microbial biomass and microbial material circulation activities.

\subsection{Nutrient Contents in Leaves and Fruits}

Nutrient contents (TN, TP, and TK) in the leaves (sampled in July) and fruit (sampled in December) in Orchards $\mathrm{C}$ and D were analyzed (Table 4). Higher levels of TN and TK in both leaves and fruits were observed in orchard C, while the TP in both leaves and fruits were higher in orchard D. In orchard C, the TN contents were $25.9 \%$ and $21.2 \%$ higher in leaves and fruits, respectively. Similarly, the TK contents were $20.2 \%$ and was $88.2 \%$ higher in the leaves and fruits, respectively. However, the TP contents in leaves and fruits of orchard D were 83.7\% and 50.0\% higher, respectively. The higher rate of release of nutrients from the decomposition of organic materials by enrichment of bacterial biomass in Orchard C may enhance the levels of TN, TP, and TK in the tree leaves and fruits.

\subsection{Suitable Soil Conditions for Organic Apple Production}

In this study, five high yielding apple orchards were selected. The average apple yield in Orchard C was 45 t/ha, which was similar to that in orchards A, B, D, and E (Table 1). Based on the high levels of bacterial biomass and nutrient circulation activities and a high level of fruit yield, the soil conditions in orchard C can be considered suitable to enhance apple production in organically fertilized soil. Similarly, the average contents of TP 

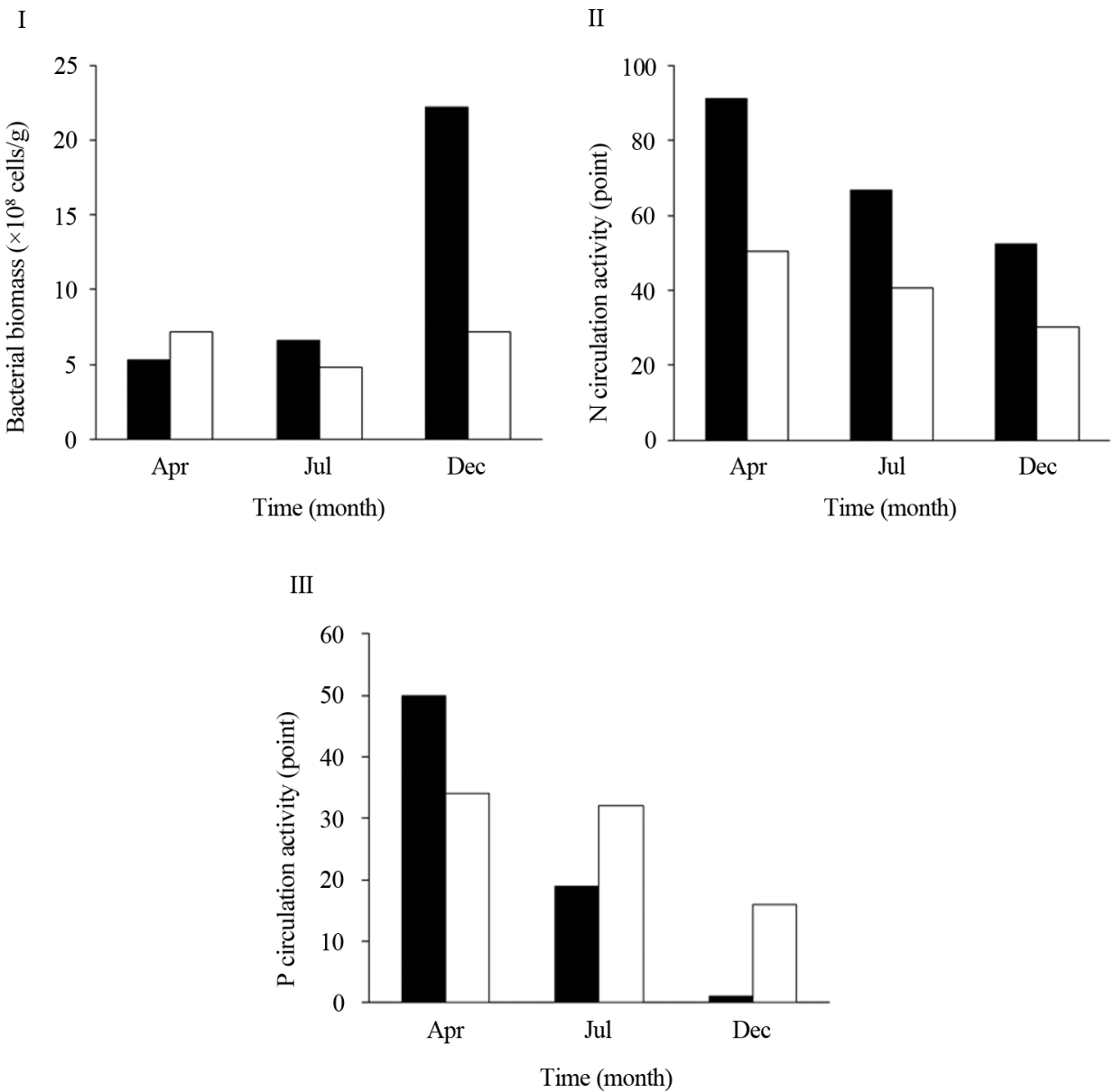

Orchard D

Figure 2. Seasonal changes in bacterial biomass (I), N circulation activity (II), and P circulation activity (III) in two orchards with different fertilizer management systems (Orchard C, organic; and Orchard D, conventional).

Table 2. Chemical properties of soils in two apple orchards (Orchards C and D).

\begin{tabular}{|c|c|c|c|c|c|c|}
\hline \multirow[t]{2}{*}{ Property } & \multicolumn{3}{|c|}{ Orchard C } & \multicolumn{3}{|c|}{ Orchard D } \\
\hline & Apr & Jul & Dec & Apr & Jul & Dec \\
\hline Total carbon (TC) (mg/kg) & 58,100 & 35,800 & 67,200 & 45,700 & 42,300 & 58,300 \\
\hline Total nitrogen $(\mathrm{TN})(\mathrm{mg} / \mathrm{kg})$ & 3000 & 1500 & 6200 & 2200 & 1600 & 2600 \\
\hline $\mathrm{C} / \mathrm{N}$ ratio & 19 & 24 & 11 & 21 & 26 & 22 \\
\hline $\mathrm{NH}_{4}^{+}-\mathrm{N}(\mathrm{mg} / \mathrm{kg})$ & 1 & 1 & 5 & 0 & 0 & 1 \\
\hline $\mathrm{NO}_{3}^{-}-\mathrm{N}(\mathrm{mg} / \mathrm{kg})$ & 4 & 6 & 0 & 0 & 0 & 9 \\
\hline Total phosphorus (TP) (mg/kg) & 8600 & 4300 & 4300 & 13,400 & 7900 & 11,300 \\
\hline Soluble phosphorus (SP) (mg/kg) & 163 & 30 & 7 & 143 & 52 & 81 \\
\hline Total potassium (TK) (mg/kg) & 7600 & 6800 & 6000 & 7100 & 4700 & 14,500 \\
\hline Soluble potassium (SK) (mg/kg) & 146 & 44 & 38 & 112 & 62 & 156 \\
\hline
\end{tabular}


Table 3. Biological properties of soils in two orchards with different fertilizer management (Orchard C, organic; and Orchard D, conventional).

\begin{tabular}{cccccccc}
\hline Property & \multicolumn{3}{c}{ Orchard C } & \multicolumn{3}{c}{ Orchard D } \\
\hline & Apr & Jul & Dec & Apr & Jul & Dec \\
\hline Bacterial biomass $\left(\times 10^{8}\right.$ cells/g) & 5.3 & 6.6 & 22.2 & 7.2 & 4.8 & 7.2 \\
$\mathrm{NH}_{4}^{+}$oxidation activity (\%) & 98 & 50 & 40 & 14 & 23 & 40 \\
$\mathrm{NO}_{2}^{-}$oxidation activity (\%) & 99 & 52 & 84 & 23 & 100 & 36 \\
$\mathrm{~N}$ circulation activity (point) & 91 & 67 & 52 & 50 & 41 & 30 \\
P mineralization activity (\%) & 50 & 19 & 1 & 44 & 32 & 16 \\
\hline
\end{tabular}

Table 4. Nutrient concentrations in leaves and fruits of apples grown in two orchards with different fertilizer management (Orchard C, organic; and Orchard D, conventional).

\begin{tabular}{|c|c|c|c|c|}
\hline Plant part and orchard & $\begin{array}{l}\text { TC (mg/kg-fresh } \\
\text { weight) }\end{array}$ & $\begin{array}{l}\text { TN (mg/kg-fresh } \\
\text { weight) }\end{array}$ & $\begin{array}{l}\text { TP (mg/kg-fresh } \\
\text { weight) }\end{array}$ & $\begin{array}{l}\text { TK (mg/kg-fresh } \\
\text { weight) }\end{array}$ \\
\hline Leaf (orchard C) & 223,400 & 14,100 & 4300 & 11,300 \\
\hline Leaf (orchard D) & 237,700 & 11,200 & 7900 & 9400 \\
\hline Fruit (orchard C) & 61,300 & 400 & 200 & 3200 \\
\hline Fruit (orchard D) & 60,800 & 330 & 300 & 1700 \\
\hline
\end{tabular}

and TK in Orchard C can be considered suitable for apple production under the organic fertilizer management system. These optimum values for organic apple production are as follows: TC from 50,000 to 60,000 mg/kg, TN from 3000 to $4000 \mathrm{mg} / \mathrm{kg}$, C/N ratio from 15 to 20, TP from 5000 to $6000 \mathrm{mg} / \mathrm{kg}$, and TK from 6000 to $7000 \mathrm{mg} / \mathrm{kg}$ (Figure 3).

\section{Discussion}

In response to concerns about health and environmental issues, there is increasing pressure to use organic agricultural systems rather than conventional or chemical systems [18] [19]. An excellent organic agricultural system is necessary to meet our demand for healthy, tasty, and nutritious foods; however, the productivity of organic agriculture is often lower than other systems [9] [20]. Control of the suitable conditions of soil for higher number and activity of microorganisms can help to enhance not only the yield but also the quality of the agricultural products.

Growth and activity of soil microorganisms are enhanced in soils rich in organic matter. In this study, a high TC content is observed in apple orchard soils (average: 45,160 mg/kg), and the values are clearly higher than those in annual uplands and paddy fields [10]. Usually, most of the plant biomass is removed under the annual croplands (such as vegetables and cereal crops), which lead to a reduction in TC content. In contrast, only fruits are harvested and other biomass remains in the field for several years in the orchards. Large amounts of fallen leaves annually result in the accumulation of carbon in the apple orchard [11] [21] [22].

In addition to TC, most of the apple orchard soils in this study are rich in TN, TP, and TK. The use of large amounts of fertilizers and decomposition of the fallen leaves are likely to have caused the accumulation of these nutrients in the orchard soils [23]. Haynes and Goh [24] report that each year approximately $30 \mathrm{~kg} \cdot \mathrm{N} \cdot \mathrm{ha}{ }^{-1} \mathrm{is}$ contained in leaves that have fallen from apple trees. The removal of accumulated nutrients may be necessary for the sustainability of orchards.

Average apple productivity in Japan is $21 \mathrm{t} / \mathrm{ha}$ (FAO, 2014), and poor soil fertility is one of the reasons for low apple production [25]. In this study, we select five high yielding apple orchards (30 to 50 t/ha), including an organically fertilized orchard (orchard C), to determine the suitable soil conditions for high levels of apple production under the organic agricultural system. Compared with the Japanese national average productivity (21 $\mathrm{t} / \mathrm{ha}$ ), almost double productivity (45 t/ha) is observed in the organically fertilized orchard. In this orchard, there is a high level of bacterial biomass and nitrogen circulation activity. In addition, levels of N, P, and K in leaves and fruits are higher in the organically fertilized orchard than in the conventionally fertilized orchard. Effec- 


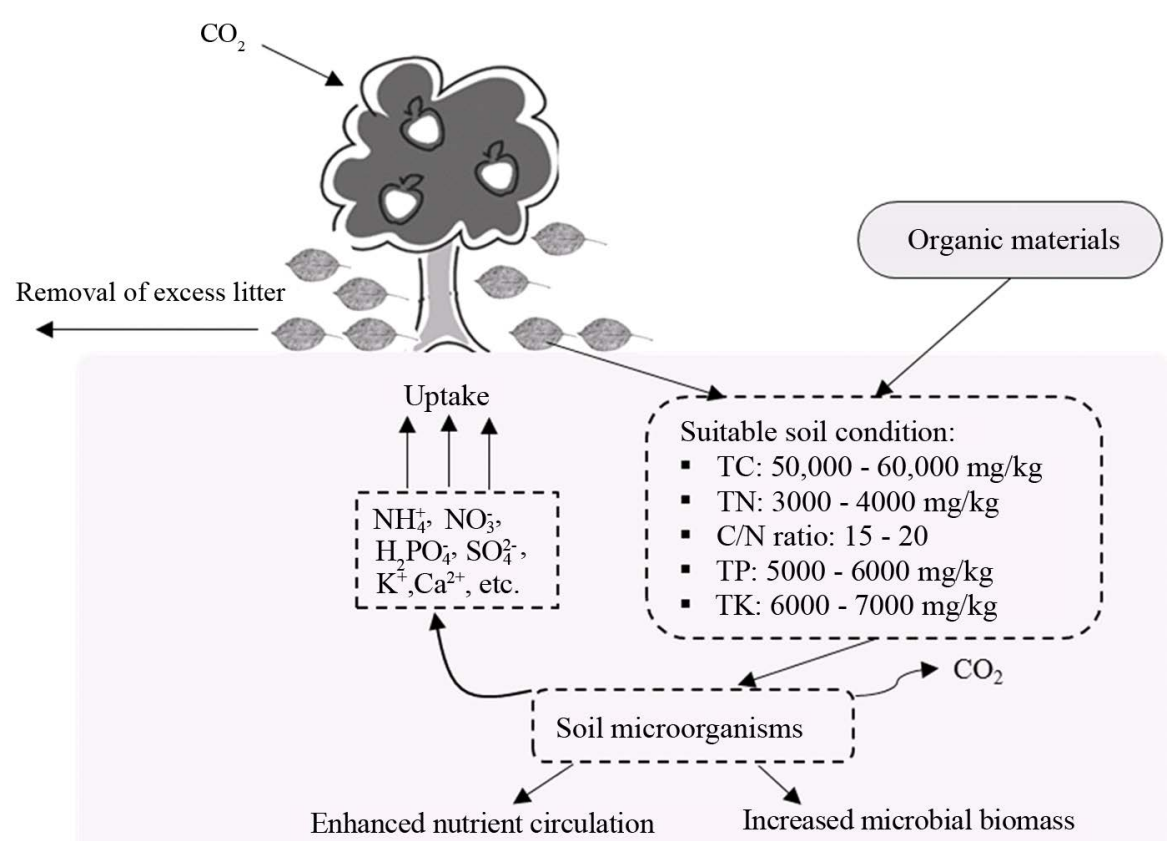

Figure 3. Schematic diagram showing the suitable conditions required for enhancing microbial numbers and nutrient circulation in soil for higher productivity of apples under the organic agricultural system.

tive management of the TC, TN, and C/N ratio in soil (TC of 50,000 - 60,000 mg/kg, TN of about $3000 \mathrm{mg} / \mathrm{kg}$, and $\mathrm{C} / \mathrm{N}$ ratio of 15 - 20) may enhance the bacterial biomass and activities; therefore, the environmental conditions in the organic orchard seem to be suitable for microbial decomposition of organic materials to increase the availability of mineral nutrients for plants [10]. Higher bacterial biomass and nitrogen circulation activities in the organically fertilized orchard (Orchard C) than in the conventionally fertilized orchard (Orchard D) also suggest that apple productivity can be improved by maintaining suitable conditions for soil microorganisms.

\section{References}

[1] Forsline, P.L., Aldwinckle, H.S., Dickson, E.E., Luby, J.J. and Hokanson, S.C. (2003) Collection, Maintenance, Characterization, and Utilization of Wild Apples of Central Asia. Horticultural Reviews: Wild Apple and Fruit Trees of Central Asia, 29, 1-62.

[2] Cornille, A., Gladieux, P., Smulders, M.J., Roldán-Ruiz, I., Laurens, F., Le Cam, B., Nersesyan, A., Clavel, J., Olonova, M., Feugey, L., Gabrielyan, I., Zhang, X.G. and Giraud, T. (2012) New Insight into the History of Domesticated Apple: Secondary Contribution of the European Wild Apple to the Genome of Cultivated Varieties. PLoS Genetics, 8, e1002703. http://dx.doi.org/10.1371/journal.pgen.1002703

[3] Krishna, K.R. (2014) Agroecosystems: Soils, Climate, Crops, Nutrient Dynamics and Productivity. Apple Academic Press, Inc., Oakville.

[4] Willer, H. and Lernoud J. (Eds.) (2015) The World of Organic Agriculture, Statistics and Emerging Trends. FiBLIFOAM Report. Research Institute of Organic Agriculture (FiBL), Frick, and IFOAM Organics International, Bonn.

[5] FAO (2014) FAOSTAT. faostat3.fao.org/home/E.

[6] Swezey, S.L., Werner, M.R., Buchanan, M. and Allison, J. (1998) Comparison of Conventional and Organic Apple Production Systems during Three Years of Conversion to Organic Management in Coastal California. American Journal of Alternative Agriculture, 13, 162-180. http://dx.doi.org/10.1017/S0889189300007876

[7] Reganold, J.P., Glover, J.D., Andrews, P.K. and Hinman, H.R. (2001) Sustainability of Three Apple Production Systems. Nature, 410, 926-930. http://dx.doi.org/10.1038/35073574

[8] Peck, G.M., Andrews, P.K., Reganold, J.P. and Fellman, J.K. (2006) Apple Orchard Productivity and Fruit Quality under Organic, Conventional, and Integrated Management. HortScience, 41, 99-107.

[9] de Ponti, T., Rijk, B. and Van Ittersum, M.K. (2012) The Crop Yield Gap between Organic and Conventional Agriculture. Agricultural Systems, 108, 1-9. http://dx.doi.org/10.1016/j.agsy.2011.12.004 
[10] Adhikari, D., Kai, T., Mukai, M., Araki, K.S. and Kubo, M. (2014) A New Proposal for a Soil Fertility Index (SOFIX) for Organic Agriculture and Development of a SOFIX Database for Agricultural Fields. Current Topics in Biotechnology, 8, 81-91.

[11] Kai, T., Mukai, M., Araki, K.S., Adhikari, D. and Kubo, M. (2015) Physical and Biochemical Properties of Apple Orchard Soils of Different Productivities. Open Journal of Soil Science, 5, 149-156 http://dx.doi.org/10.4236/ojss.2015.57015

[12] Agricultural Policy and Planning Department of Nagano Prefecture (2014) Pesticide Use Criteria in Apple. (In Japanese)http://www.pref.nagano.lg.jp/bojo/yaku/index.html

[13] Donald Nicholas, D.J. and Nason, A. (1957) Determination of Nitrate and Nitrite. Methods in Enzymology, 3, $981-984$. http://dx.doi.org/10.1016/S0076-6879(57)03489-8

[14] Murphy, J. and Riley, J.P. (1962) A Modified Single Solution Method for the Determination of Phosphate in Natural Waters. Analytica Chimica Acta, 27, 31-36. http://dx.doi.org/10.1016/S0003-2670(00)88444-5

[15] Aoshima, H., Kimura, A., Shibutani, A., Okada, C., Matsumiya, Y. and Kubo, M. (2006) Evaluation of Soil Bacterial Biomass Using Environmental DNA Extracted by Slow-Stirring Method. Applied Microbiology and Biotechnology, 71, 875-880. http://dx.doi.org/10.1007/s00253-005-0245-X

[16] Matsuno, T., Horii, S., Sato, T., Matsumiya, Y. and Kubo, M. (2013) Analysis of Nitrification in Agricultural Soil and Improvement of Nitrogen Circulation with Autotrophic Ammonia-Oxidizing Bacteria. Applied Biochemistry and Biotechnology, 169, 795-809. http://dx.doi.org/10.1007/s12010-012-0029-6

[17] Horii, S., Matsuno, T., Tagomori, J., Mukai, M., Adhikari, D. and Kubo, M. (2013) Isolation and Identification of Phytate-Degrading Bacteria and Their Contribution to Phytate Mineralization in Soil. The Journal of General and Applied Microbiology, 59, 353-360. http://dx.doi.org/10.2323/jgam.59.353

[18] Carvalho, F.P. (2006) Agriculture, Pesticides, Food Security and Food Safety. Environmental Science and Policy, 9, 685-692. http://dx.doi.org/10.1016/j.envsci.2006.08.002

[19] Lairon, D. (2010) Nutritional Quality and Safety of Organic Food. A Review. Agronomy for Sustainable Development, 30, 33-41. http://dx.doi.org/10.1051/agro/2009019

[20] Seufert, V., Ramankutty, N. and Foley, J.A. (2012) Comparing the Yields of Organic and Conventional Agriculture. Nature, 485, 229-232. http://dx.doi.org/10.1038/nature11069

[21] Kumar, K. and Goh, K.M. (1999) Crop Residues and Management Practices: Effects on Soil Quality, Soil Nitrogen Dynamics, Crop Yield, and Nitrogen Recovery. Advances in Agronomy, 68, 197-319. http://dx.doi.org/10.1016/S0065-2113(08)60846-9

[22] Tonon, G., Ciavatta, C., Solimando, D., Gioacchini, P. and Tagliavini, M. (2007) Fate of ${ }^{15}$ N Derived from Soil Decomposition of Abscised Leaves and Pruning Wood from Apple (Malus domestica) Trees. Soil Science and Plant Nutrition, 53, 78-85. http://dx.doi.org/10.1111/j.1747-0765.2007.00112.x

[23] Tagliavini, M., Tonon, G., Scandellari, F., Quinones, A., Palmieri, S., Menarbin, G., Gioacchini, P. and Masia, A. (2007) Nutrient Recycling during the Decomposition of Apple Leaves (Malus domestica) and Mowed Grasses in an Orchard. Agriculture, Ecosystems and Environment, 118, 191-200. http://dx.doi.org/10.1016/j.agee.2006.05.018

[24] Haynes, R.J. and Goh, K.M. (1980) Some Effects of Orchard Soil Management on Sward Composition, Levels of Available Nutrients in the Soil, and Leaf Nutrient Content of Mature “Golden Delicious” Apple Trees. Scientia Horticulturae, 13, 15-25. http://dx.doi.org/10.1016/0304-4238(80)90017-5

[25] Fujisawa, M. and Kobayashi, K. (2013) Shifting from Apple to Peach Farming in Kazuno, Northern Japan: Perceptions of and Responses to Climatic and Non-Climatic Impacts. Regional Environmental Change, 13, 1211-1222. http://dx.doi.org/10.1007/s10113-013-0434-6 